\title{
Heavy Metal Sensor Research Based on Microbial Fuel Cell
}

\author{
Yining Wu ${ }^{1,}$,, Ya Gao ${ }^{1}$, Ling Wang ${ }^{1, ~ *, ~ H o n g ~} \mathrm{Qi}^{2}$ \\ ${ }^{1}$ State Key Laboratory of Urban Water Resource and Environment, Harbin Institute of Technology, Harbin, China \\ ${ }^{2}$ School of Environment, Harbin Institute of Technology, Harbin, China
}

Email address:

18846828450@163.com (Ling Wang),wynhit@sina.com (Yining Wu)

${ }^{*}$ Corresponding author

\section{To cite this article:}

Yining Wu, Hong Qi, Ya Gao, Ling Wang. Heavy Metal Sensor Research Based on Microbial Fuel Cell. International Journal of Environmental Monitoring and Analysis. Vol. 6, No. 2, 2018, pp. 53-64. doi: 10.11648/j.ijema.20180602.13

Received: January 30, 2018; Accepted: June 6, 2018; Published: June 20, 2018

\begin{abstract}
In this study, a single chamber microbial fuel cell (MFC) was developed for heavy metal (copper ions) sensor with different concentrations at cathode, and its electrochemical activities in batch-mode operation including polarization curve, power density, anode potential, cathode potential and 30 minutes real-time voltage were characterized and studied. Under the condition of $1000 \Omega$ external resistance, $100 \mathrm{mM}$ PBS buffer and $1000 \mathrm{mg} / \mathrm{L} \mathrm{COD}$, results indicated that the real-time voltage of $30 \mathrm{~min}$ collected by the data acquisition was linearly developed with the change of concentration gradient, and the polarization curve showed that copper ion concentration and power density reflect a trend of X squared. In addition, the anode and cathode potential collected by the multimeter, also showed a trend of $\mathrm{X}^{2}$. By studying the relationship between electrochemical parameters and heavy metal ion concentration, a reliable correlation could be established to help us to use the detected electrochemical parameters to estimate the concentration of heavy metal ions in the environment of sewage pollution, so as to provide theoretical support for the development of new heavy metal sensors. The results provided new ideas for the practical application of microbial fuel cells.
\end{abstract}

Keywords: Microbial Fuel Cell (MFC), Heavy Metal Sensor, Copper Ions, Cathode

\section{Introduction}

Microbial fuel cell (MFC) as a promising technology for treating wastewater while recovering bioenergy, has been studied to remove different kinds of waste substance [1]. It is a new type of biomass energy, which can alleviate China's energy crisis [2]. In the anode surface, the electrogenic microorganisms degrade organic pollutants in sewage while generating electrons, which then transfer to the cathode through external circuit and complete the reduction reactions with electron acceptors in the cathode. At present, researchers have found that there is a high removal rate of heavy metal treatment in MFCs, especially for Fe (III) and Cr(VI) etc [3-5].

The heavy metal wastewater, after treated by bio electrochemical system, can remove heavy metal ions and also produce hydrogen, methane and other clean energy. The system is a method which has a good prospect of development, mainly using electricigens in anode, the pollutants in sewage as nutrients produce electrons through their own metabolic activity, which are transfered to the cathode then. Heavy metal ions can be removed by electron reduction reaction. At present, there are many methods of heavy metal ion monitoring, of which, biological sensors has a very good development, using a biological sensitive element produces a corresponding electrical signal with the change of ions concentration. To complete the identification process.

The testing equipment, need a immobilized biological sensitive sensor as recognition element, and a signal converter to amplifies the physicochemical analysis.

However, it is hard to be put into pilot scale or practice because of its limitation in volume size, which greatly hinder the development of MFCs in heavy metal treatment and power generation. So researchers explore the potentials of MFCs as a biosensors [6-12], which do not require a physical or chemical converter and has the characteristics of biosensors, also is easier to achieve the formation as an on- 
line monitoring biosensor [13-15].

Based on the characters of microorganisms at electrode, electrochemical parameters in microbial fuel cell with different concentrations of copper ions were investigated to find changes in electrochemical activities and then researchers explored its application in heavy metal sensors [16-17].

\section{Materials and Methods}

\subsection{Experimental Operation}

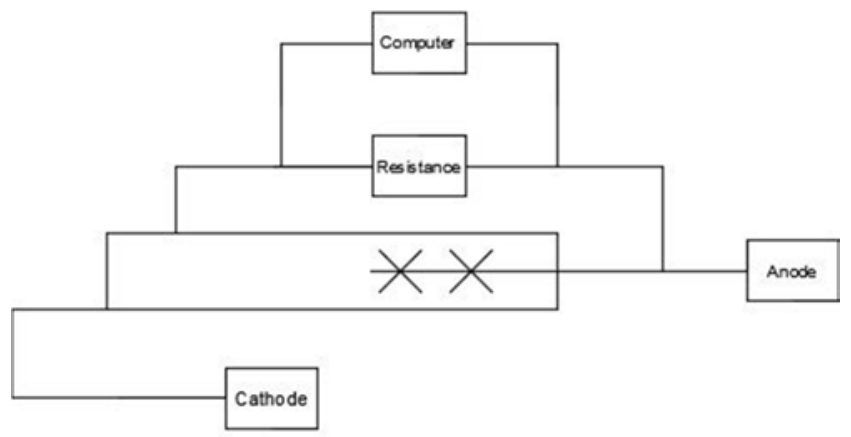

Figure 1. The schematic diagram of $M F C$.

The microbial fuel cell was a volume of $28 \mathrm{~mL}$ single chamber, with carbon brush as the anode and $\mathrm{Pt} / \mathrm{C}$ carbon cloth coated with a waterproof layer as the cathode as shown in Figure 1. The reactor was started under the conditions, where the external resistance was $1000 \Omega$, the initial $\mathrm{pH}$ value was $6.48 \mathrm{~g} / \mathrm{L}$, The temperature was $35 \pm 1^{\circ} \mathrm{C}$. The sludge inoculated in the single chamber was from the UASB mature sludge, the entire device connected with the data acquisition card to record the generated voltage.

\subsection{Experimental Methods}

With the concentration of copper ions varying from 1 to 12 $\mathrm{mg} / \mathrm{L}$, the voltage was recorded by the data acquisition card during the experiment. Polarization curve and power density curve measurement was conducted using electrochemical workstation (METASH, China) with different Rext through adjustable resistance box (ZX21 laboratory DC resistance box, Shanghai Li Chun quiet Instrument Co., Ltd.),. The anode and cathode potential were recorded using Multimeter (VC9808 +, Shenzhen victory multimeter) and reference electrode; COD and Coulomb efficiency measurement was measured according to national standards. The removal rate of copper ions was detected by spectrophotometry (UV-6000, Shanghai Cheng hua Instrument Co., Ltd.). X-ray electron spectrometer ESCALAB250Xi (Thermo Fisher Scientific, USA).

\section{Results and Discussion}

\subsection{MFC Start-up and Domestication}

Results including the polarization curves, power density curves, electrode potentials, and COD removal were compared in the start-up and acclimation processes. As shown in Figure 2A, when the single chamber MFC was acclimated and run for $500 \mathrm{~h}$ with $1 \mathrm{mg} / \mathrm{L}$ copper ion, the voltage was improved slightly and reached $0.56 \pm 0.01 \mathrm{~V}$, which indicated that the initial copper ions were enough to meet the requirement of microelements of the microbe at electrodes.

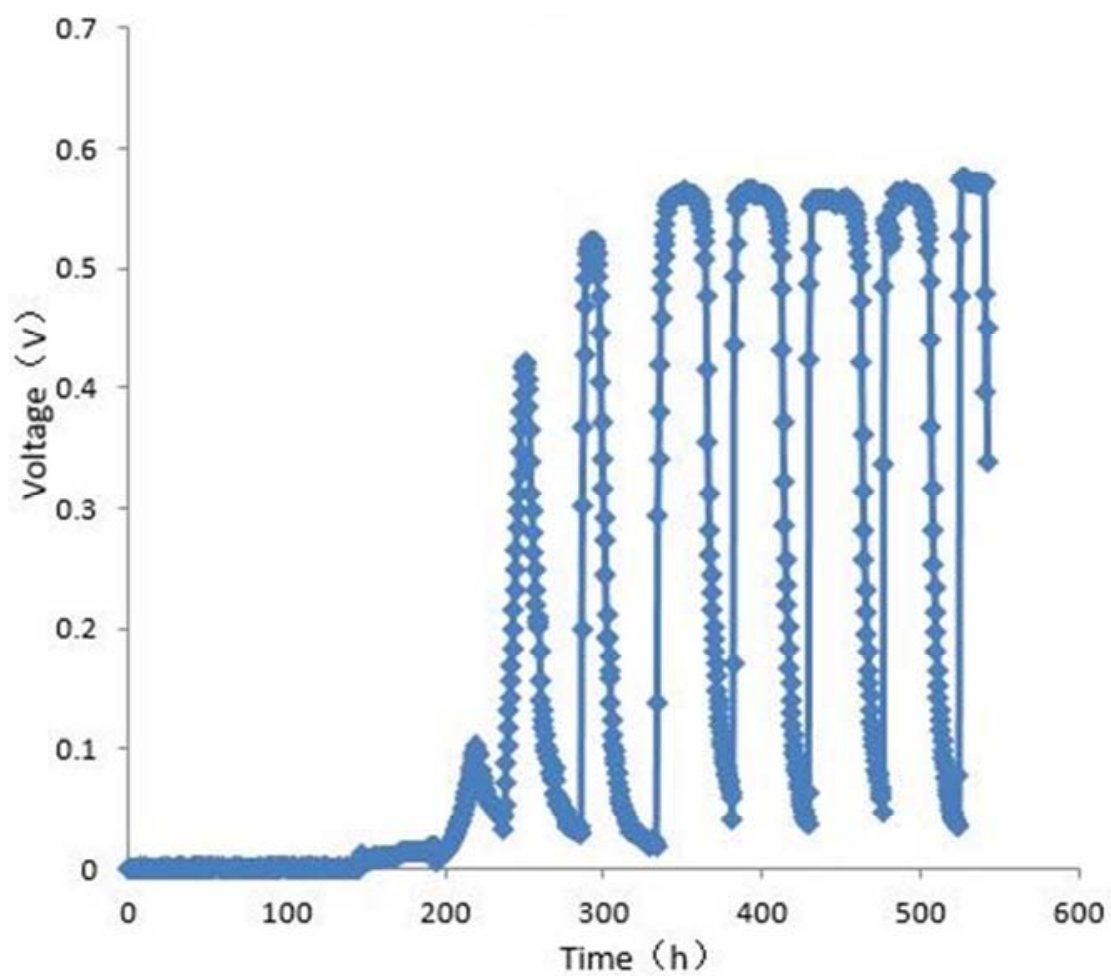

(A) 


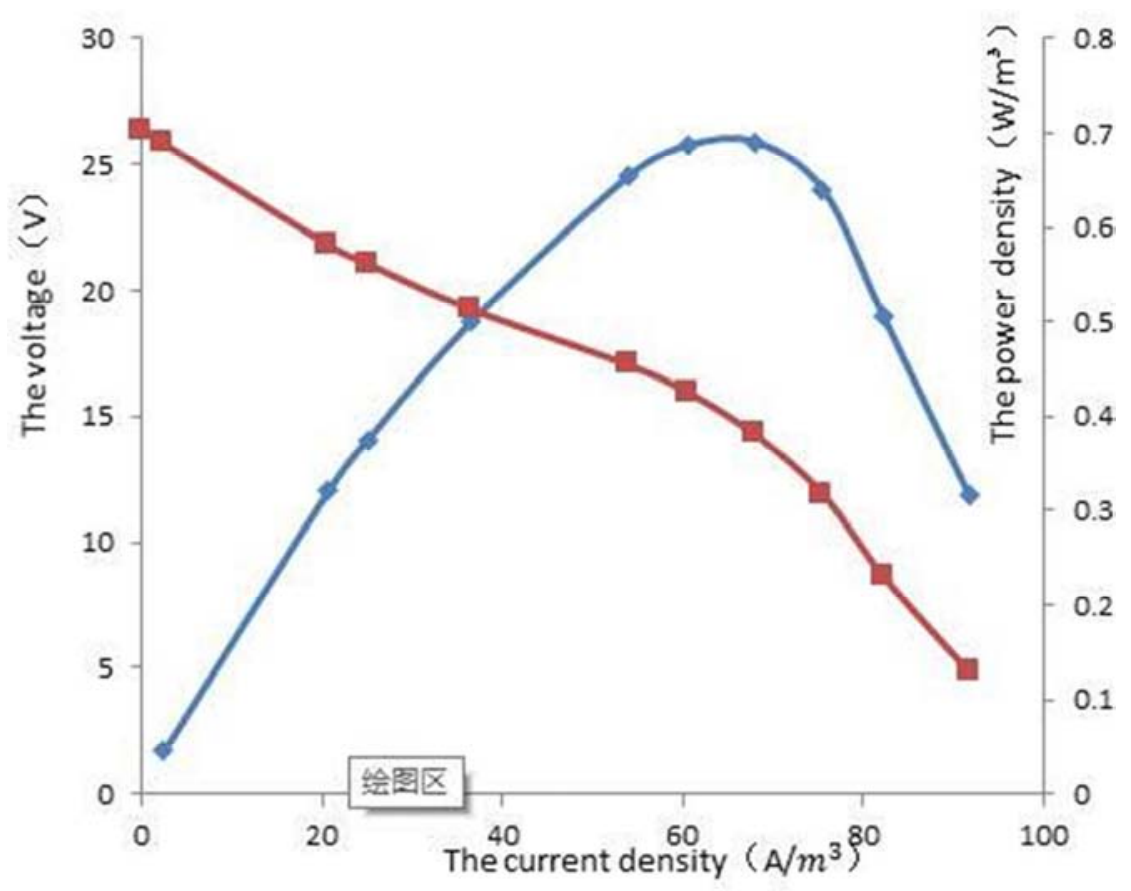

(B)

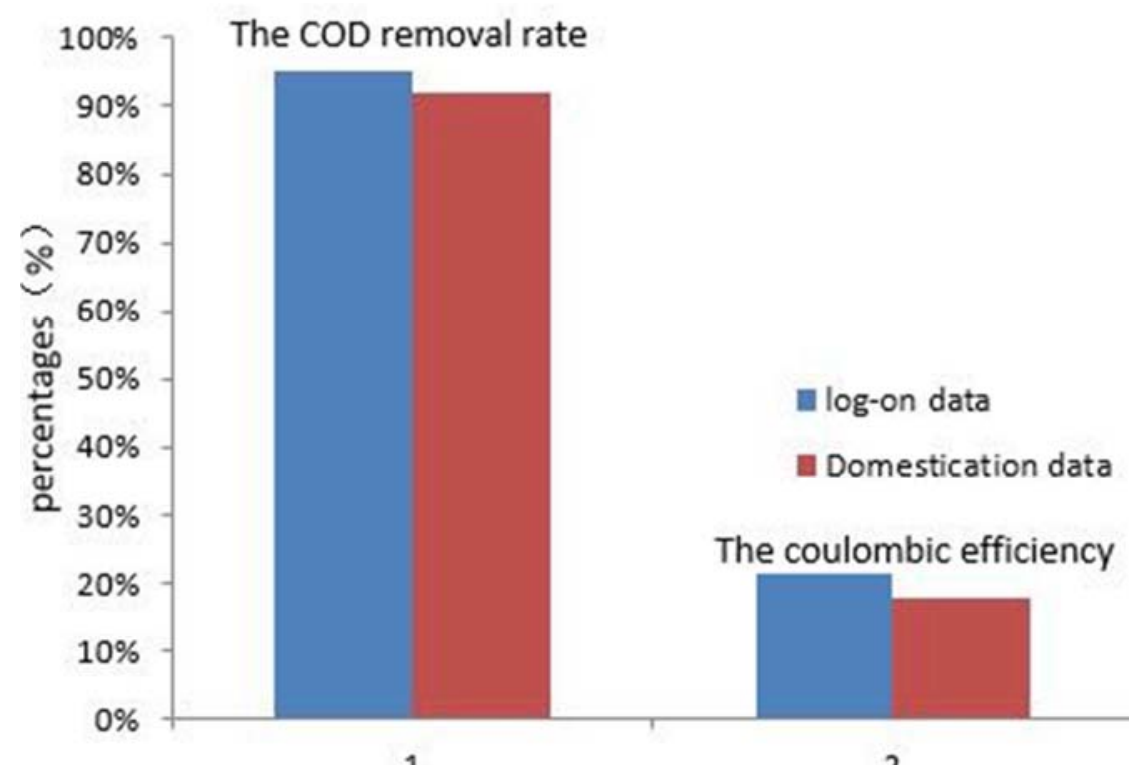

(C)

Figure 2. (A) 30 min voltage graph; (B) polarization powermap; (C) CE and COD removal rate.

From the results of Figure 2 (A) and (C), it also indicated the successful start-up and the normal reactivity of the MFC, in which the electrochemical parameters were stable and the COD removal rate was high.

\subsection{Microscopic Characterization of the Surface of Copper Ion Cathode Material}

In order to analyze the pathway of $\mathrm{Cu}$ (II) in the MFC, the cathode material of the MFC reactor in stable operation period was characterized by XPS after pretreatment so that the change of the surface elements of the cathode could be found more intuitively. The results were shown in Figure 3. 


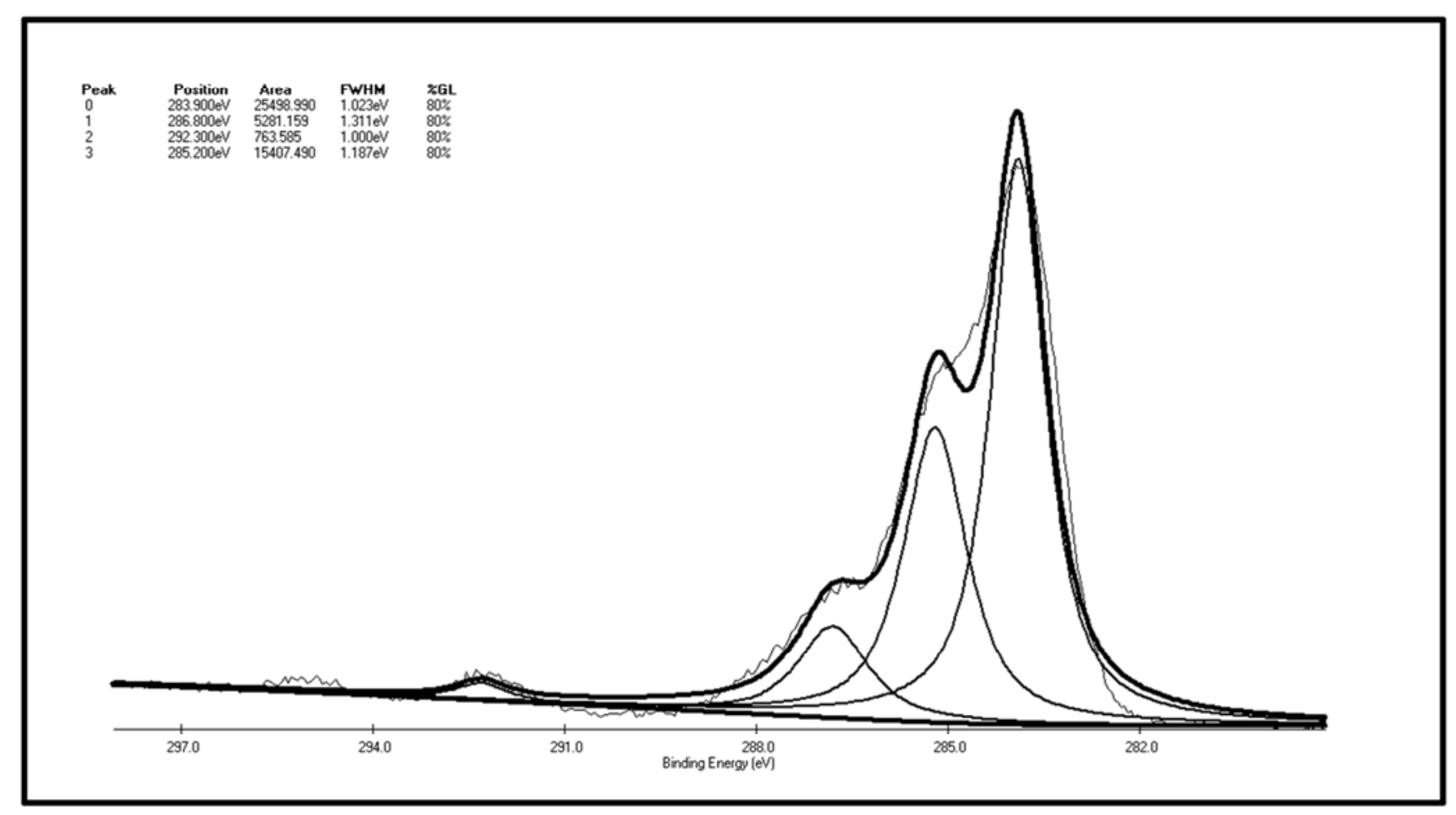

A

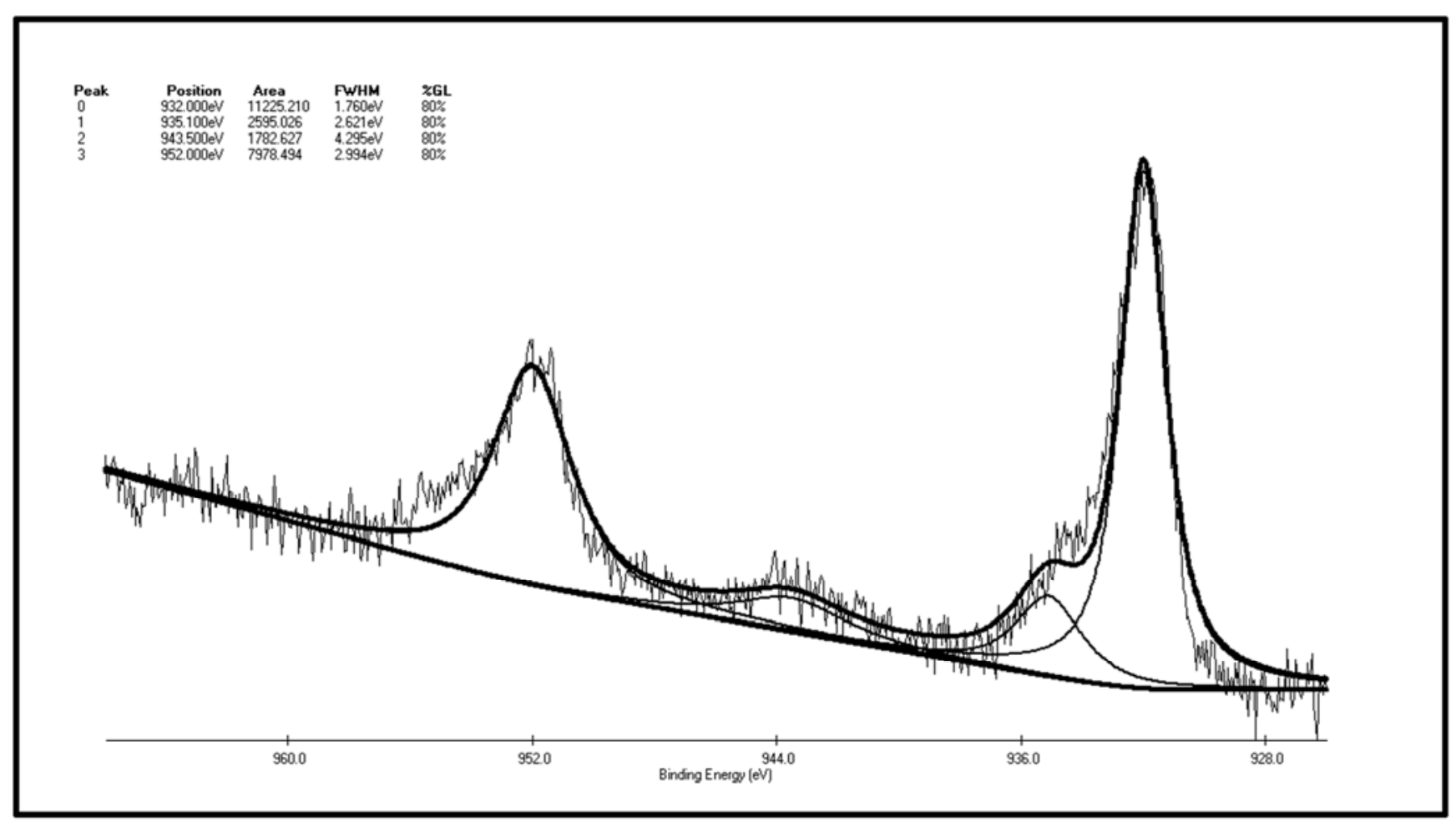

B

Figure 3. A XPS peak of Carbon element; B XPS peak of Copper element.

By comparing the standard spectra of XPS, the peak of $\mathrm{C} 1 \mathrm{~s}$ was found at $284.8 \mathrm{eV}$, the peak of the cathode material was $283.900 \mathrm{eV}$, the deviation was $0.9 \mathrm{ev}$. As shown in Fig 3 (A), peaks were 283.900, 286.800, 292.300 and 285.200 ev, and the corrected positions were 284.800, 287.700,
293.200 and $286.100 \mathrm{eV}$. After fitted, the peak position of $\mathrm{Cu} 2 \mathrm{p}$ were 932.000, 935.100, 943.500 and $952.000 \mathrm{eV}$, respectively, It should be noted that $\mathrm{Cu} 2 \mathrm{p}^{1 / 2}$ peak area is relatively large with about $33.84 \%$ at the peak of $952.000 \mathrm{eV}$. The position of $\mathrm{Cu} 2 \mathrm{p}^{3 / 2}$ peak was at $932.000 \mathrm{eV}$, 
which indicated that the existence of copper probably in the form of $\mathrm{Cu}(\mathrm{I})$ or $\mathrm{Cu}(0)$ was precipitated in the surface of cathode electrode. As for the two small peaks of 943.500 and $935.100 \mathrm{ev}$, the area was about $18.55 \%$ of all. It was speculated that copper deposited in the form of $\mathrm{Cu}$ (II), such as $\mathrm{Cu}(\mathrm{OH})_{2}$, but the specific proportion of sediments could not be estimated.

\subsection{Electrochemical Parameters of the MFC for Different Concentrations of $\mathrm{Cu}$ (II)}

The electrochemical characters of the single chamber MFC were investigated with different concentrations of copper ion (from $1 \mathrm{mg} / \mathrm{L}$ to $12 \mathrm{mg} / \mathrm{L}$, with per $1 \mathrm{mg} / \mathrm{L}$ as a gradient), which were added to the reactor in accordance with the gradient respectively from $1 \mathrm{mg} / \mathrm{L}$ to $12 \mathrm{mg} / \mathrm{L}$, as shown in Figure 4.

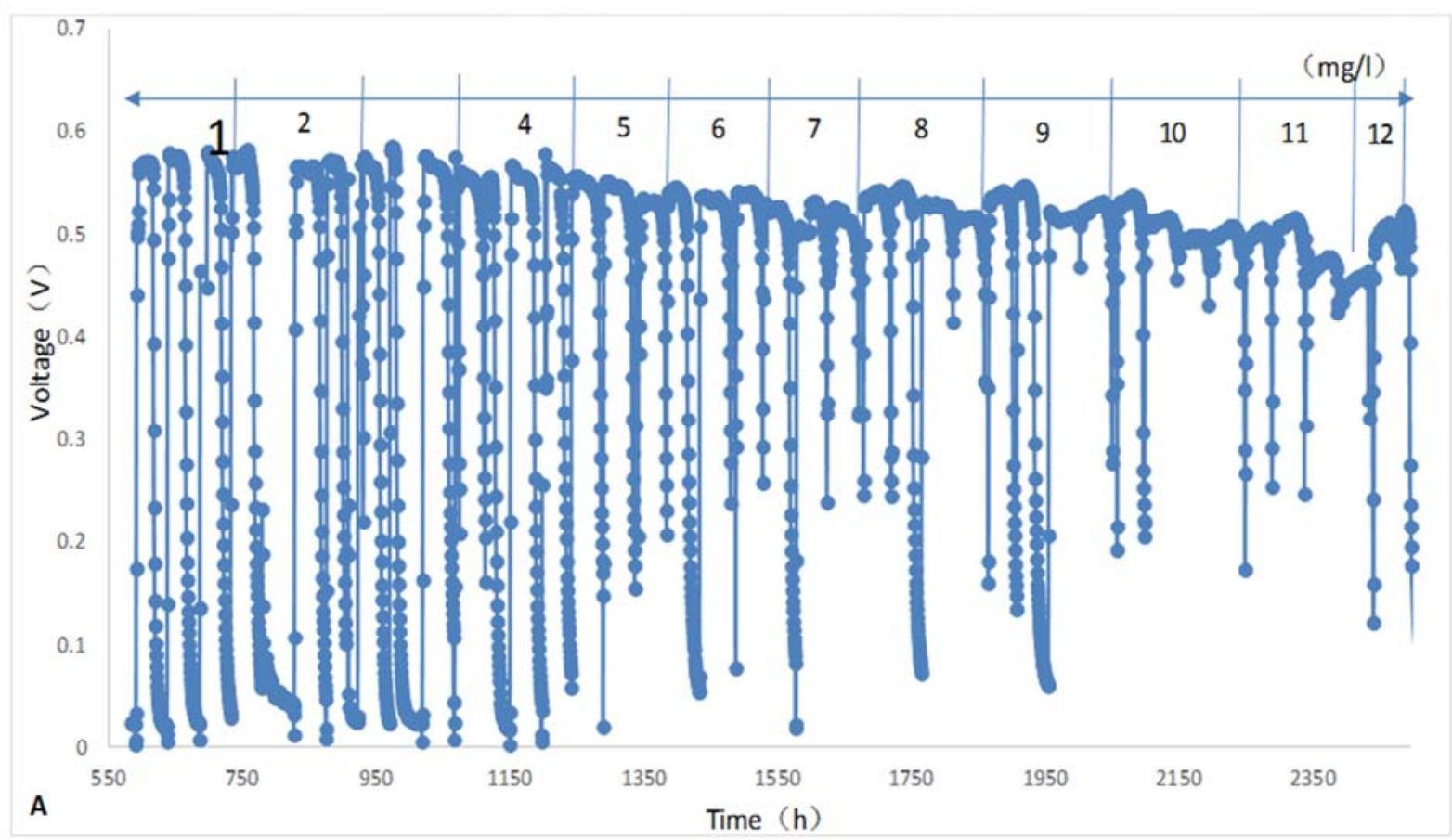

(A)

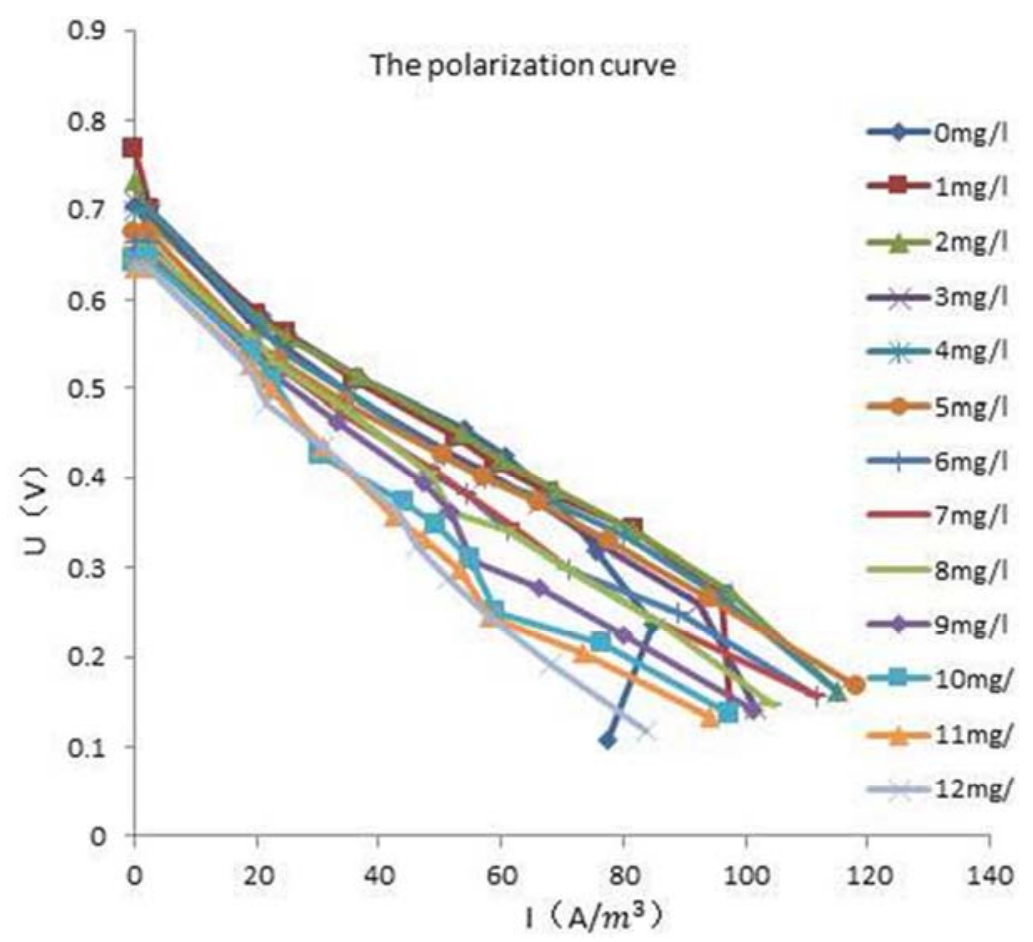

(B) 


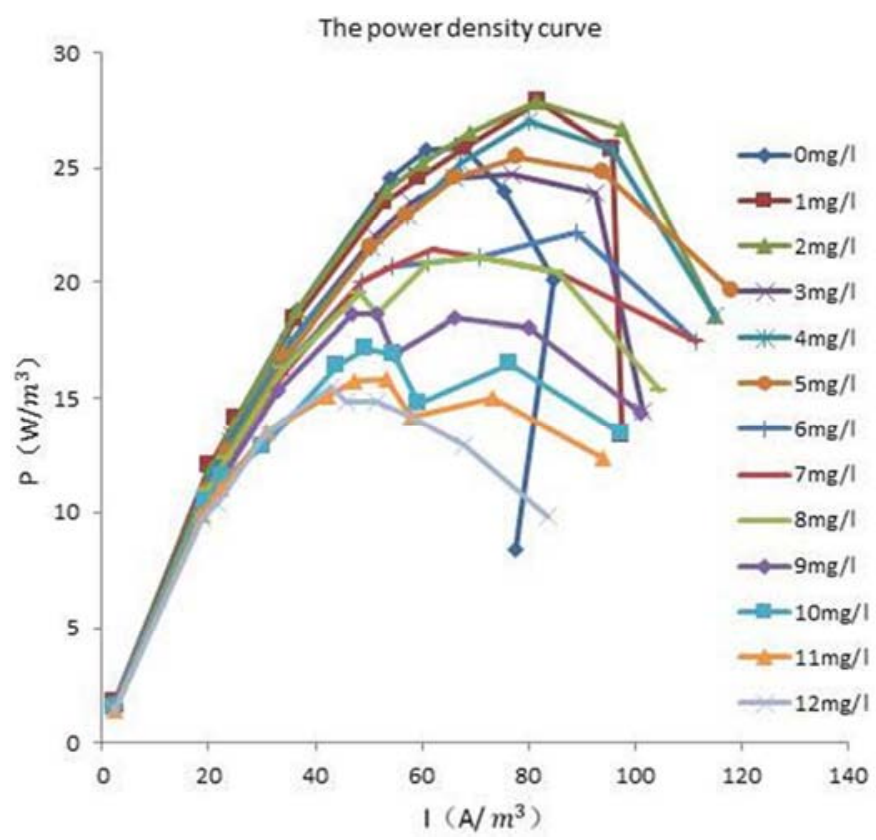

(C)

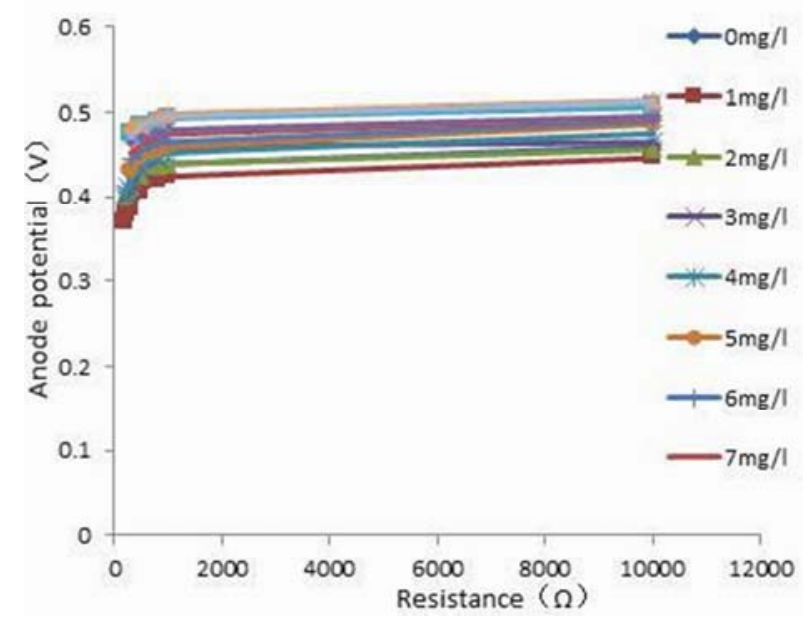

(D)

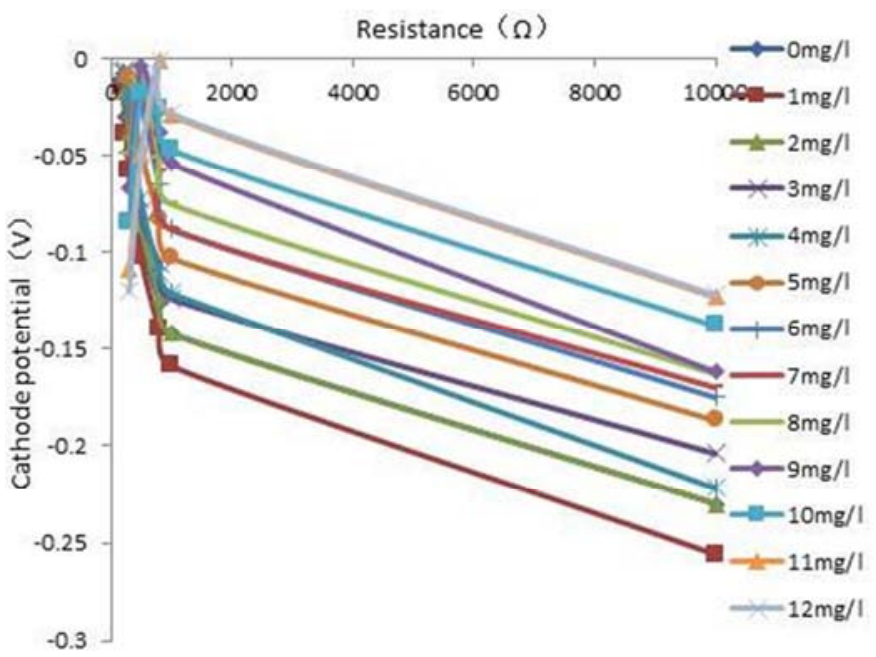

(E)

Figure 4. (A) The voltage of the MFC with different Cu concentrations from 1 to $12 \mathrm{mg} / \mathrm{L}$; (B)The polarization curve; (C) The power density curve; (D) Anode potential diagram; (E) Cathode potential diagram. 
From the voltage results in Figure 4, there was an obvious decrease of maximum voltage with the increase concentration of $\mathrm{Cu}$. In the whole process, the voltage was slightly decreased from $0.78 \mathrm{eV}$ to $0.62 \mathrm{eV}$ as the $\mathrm{Cu}$ concentration increased from 1 to $12 \mathrm{mg} / \mathrm{L}$, which indicated that the poisoning effect of copper ion on biofilm at the electrodes was in the acceptable range. It might be that with the degradation and the corresponding enzyme, the microorganism could maintain normal activity, resulting in the normal operation of the reactor.

The polarization curves of MFC with different $\mathrm{Cu}$ concentrations showed that as the $\mathrm{Cu}$ concentration increased from 1 to $12 \mathrm{mg} / \mathrm{L}$, the power density first increased from 13 to $28 \mathrm{~W}$, then decreased from 8 to $18 \mathrm{~W}$ (Figure $4 \mathrm{~B}$ ). It indicated that in the early degradation of organic matter, microorganisms could reduce the toxic effects of copper ions to maintain the corresponding activity through their own metabolism. However, with the ions concentration increased, the toxicity inhibition become more serious, affecting the enzyme activity of microbial cell and leading to its lower electron transfer activity. Also from Figure4(C) the current density and the power density decreased too, but in the whole period of increasing $\mathrm{Cu}$ concentrations in the MFC, it could be seen that all the physiological characteristics of microorganisms were still in a steady state.

Compared to the voltage, power density and the current density of the MFC, the change of the anode and cathode potentials was more obvious from Figure4(E). The relationship between the MFC performance and the different $\mathrm{Cu}$ concentration was more obvious as shown in Figure 4E. For the reaction mechanism of the microbial fuel cell, the change of the concentration of heavy metal ions would directly affect the life activities of microorganisms, while the microorganisms were colonized on the anode carbon brush, thus the change of the anode and cathode potential with different $\mathrm{Cu}$ concentrations would be much more directly related with the biofilm of anode electrode.

In order to analyze the performance of the MFC reactor with a series of copper ion concentration gradients' experiments, COD was investigated. Results indicated that the removal rate of COD was in the range of $90 \pm 9 \%$ and the removal rate of $\mathrm{Cu}$ was $90 \pm 8 \%$, reflecting the $\mathrm{MFC}$ reactor was running well in the whole process, the microbial activity cycle was in a stable state, as shown in Figure 5.

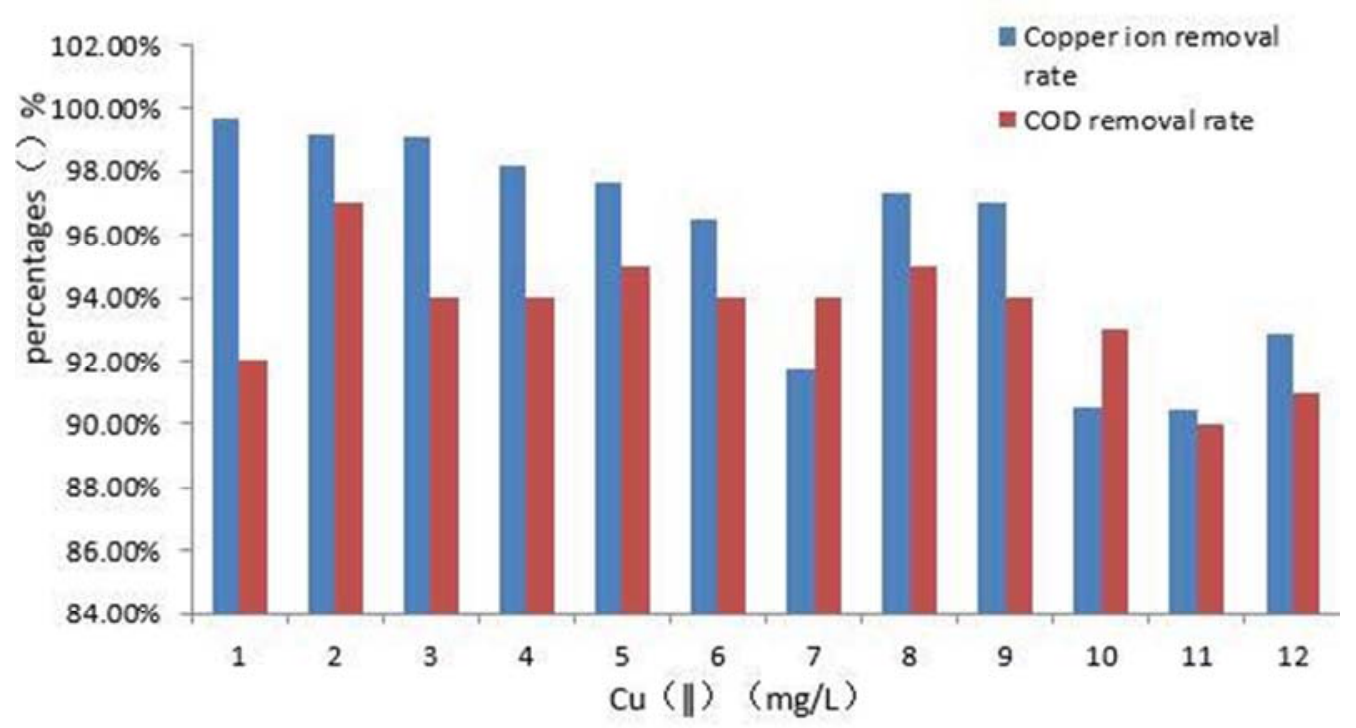

Figure 5. Copper ion, COD removal rate.

\subsection{Characterization of Electrochemical Parameters}

In the response of the electrochemical level, it showed that the collected real- time voltage data changed linearly as the $\mathrm{Cu}$ (II) concentration increased from 0 to $12 \mathrm{mg} / \mathrm{L}$, the equation was $\mathrm{Y}=-0.008 \mathrm{X}+0.588$, where the determination coefficient $\left(\mathrm{R}^{2}\right)$ was 0.966 . The determination coefficient on behalf of the fitting degree between the existing data and the equation (trend line), the closer the value to 1 the better the fit was, namely the equation was more consistent with the existing laws of the existing data. The other parameters, such as the current density, power density, and anode or cathode potential etc. all had the relation of $\mathrm{X}^{2}$, and the over all trend was also consistent with relationship. Considering from the simplicity and convenience of biosensor, real-time voltage could be used as the electrochemical characterization parameters. 


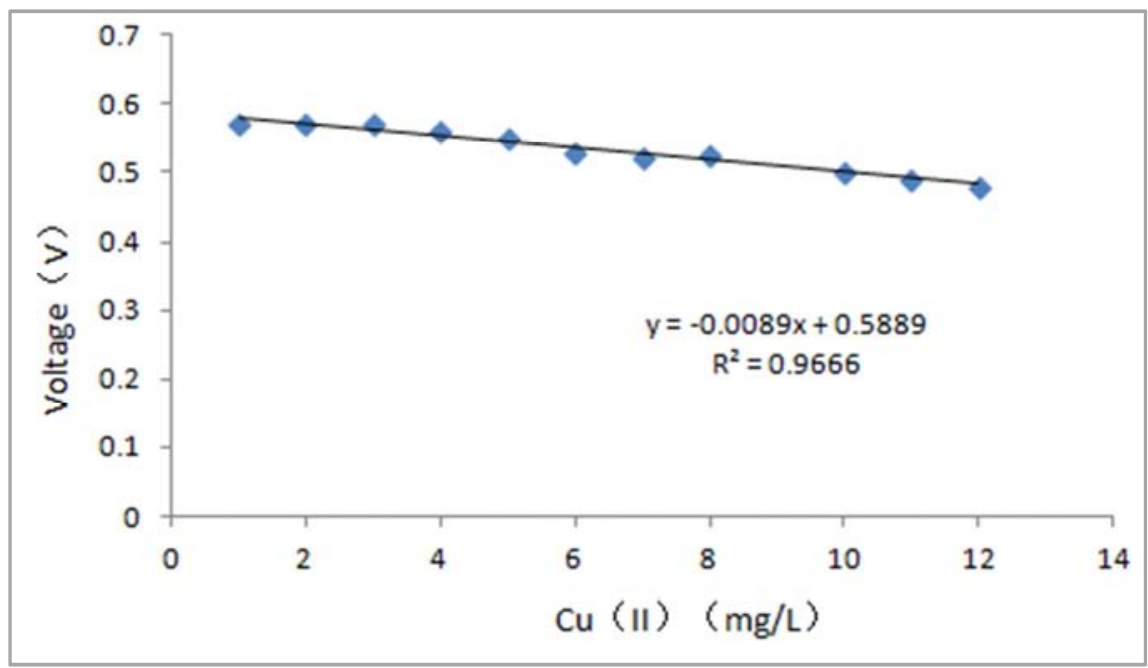

(A)

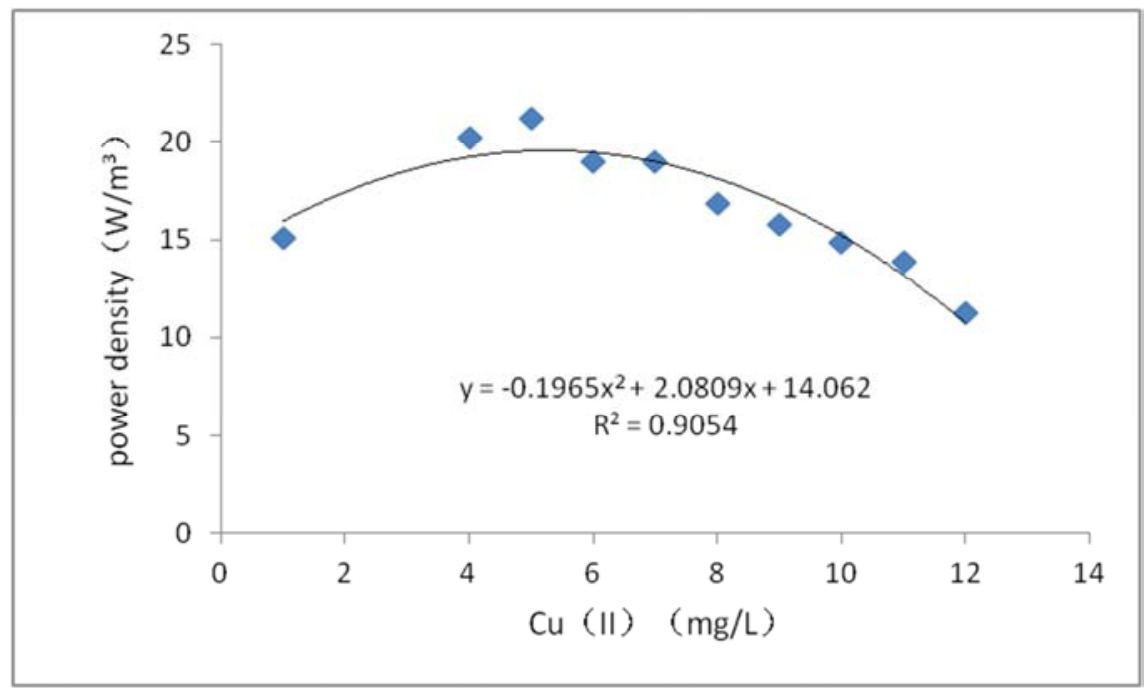

(B)

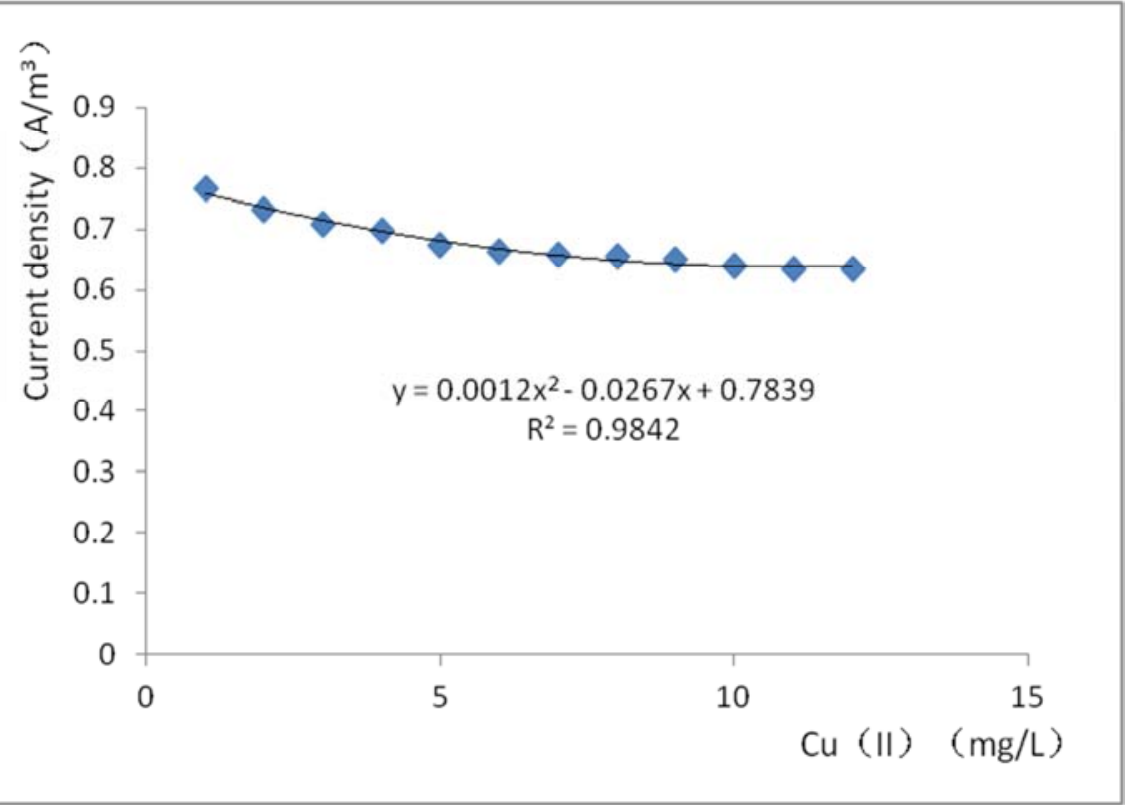

(C) 


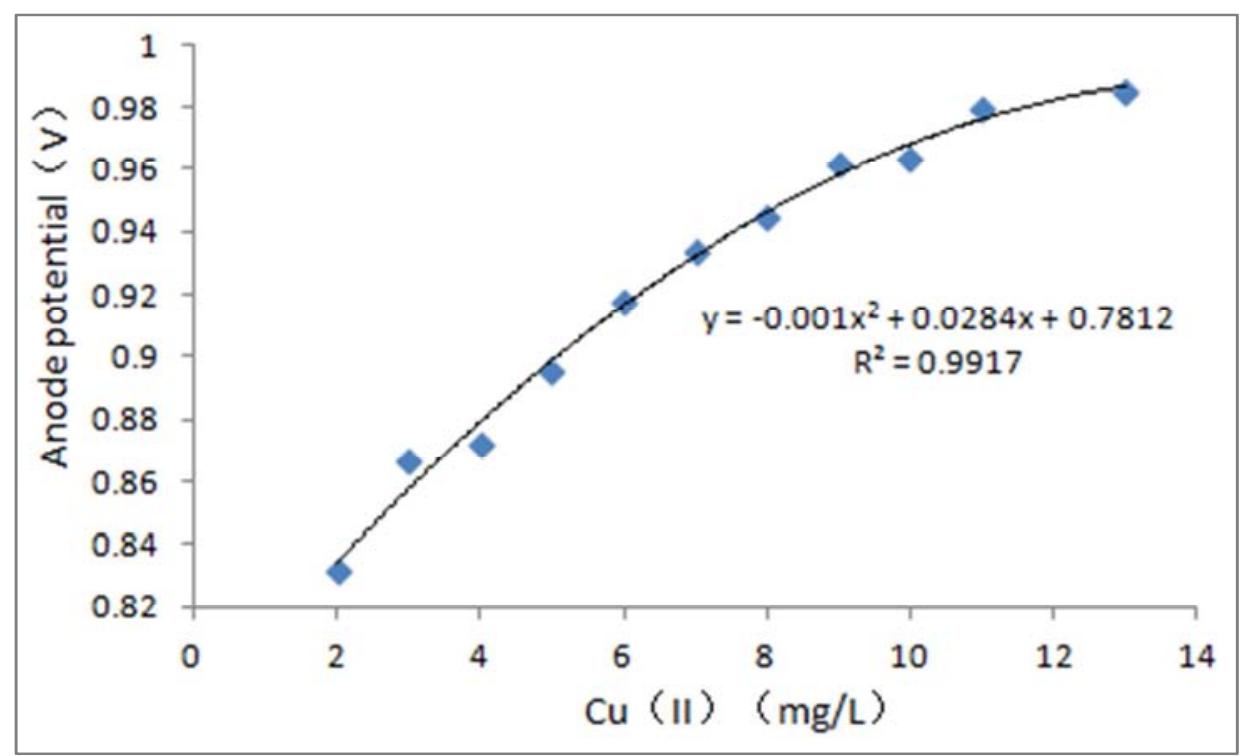

(D)

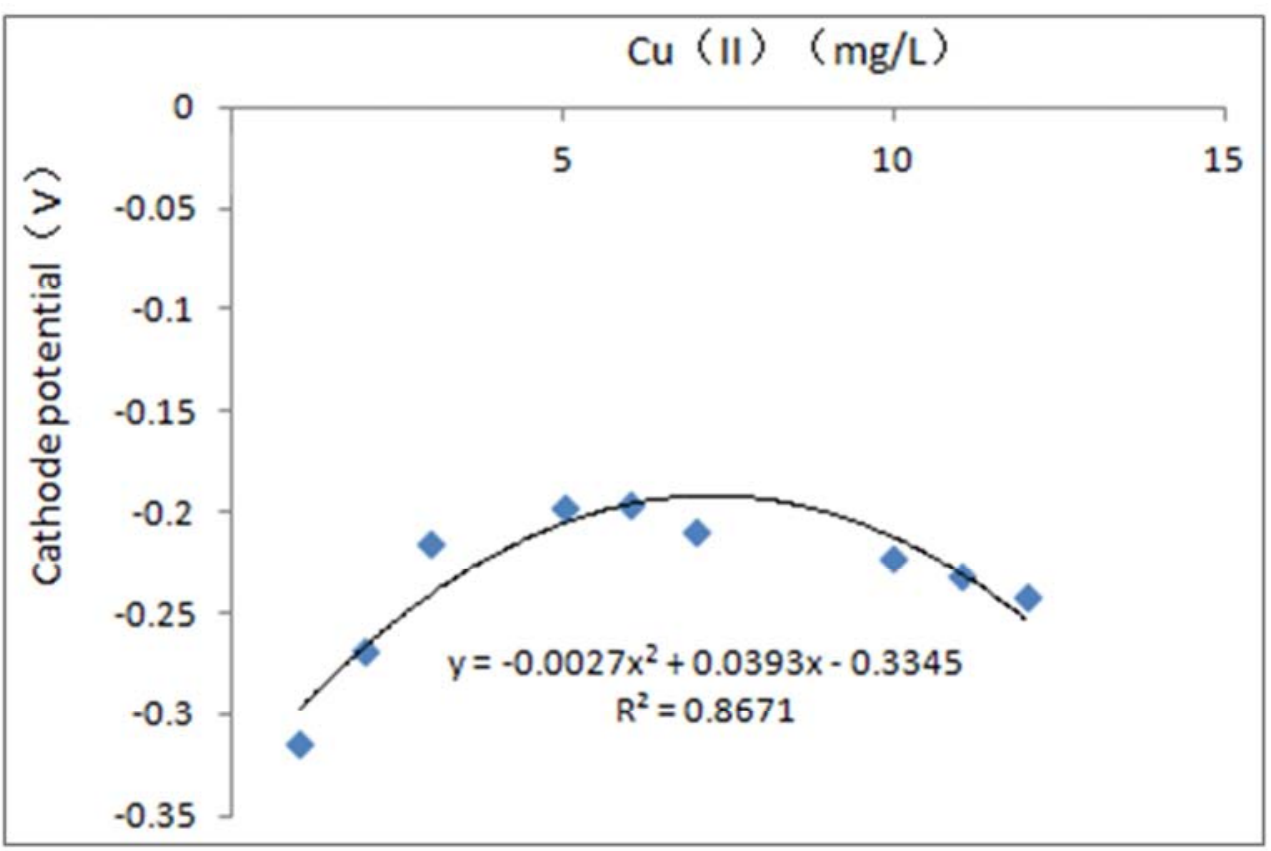

(E)

Figure 6. (A) 30min voltage variation trend; (B) the power density change in trend; (C) current density variation trend; (D) changes the anode potential trend; (E) the cathode potential trends with different $\mathrm{Cu}$ concentrations in the MFC.

\subsection{Effect of COD on Characterization}

In the experiment of heavy metal sensor, in order to study the effect of influent COD on its electrochemical characterization, five different concentrations of COD $(500,800,1100,1400,1700 \mathrm{mg} / \mathrm{L})$ were used to observe the change of electrochemical parameters, respectively, including the polarization curve, power density curve, and the electrode potential (as shown in Figure 7). 


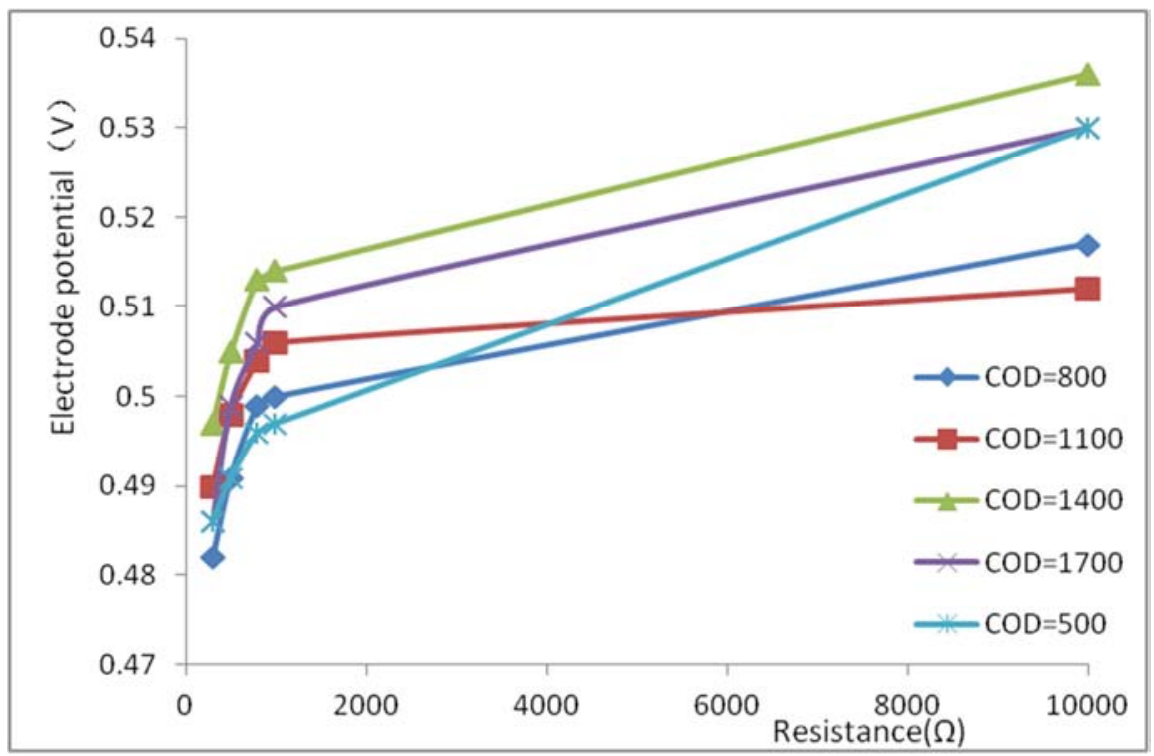

(A)

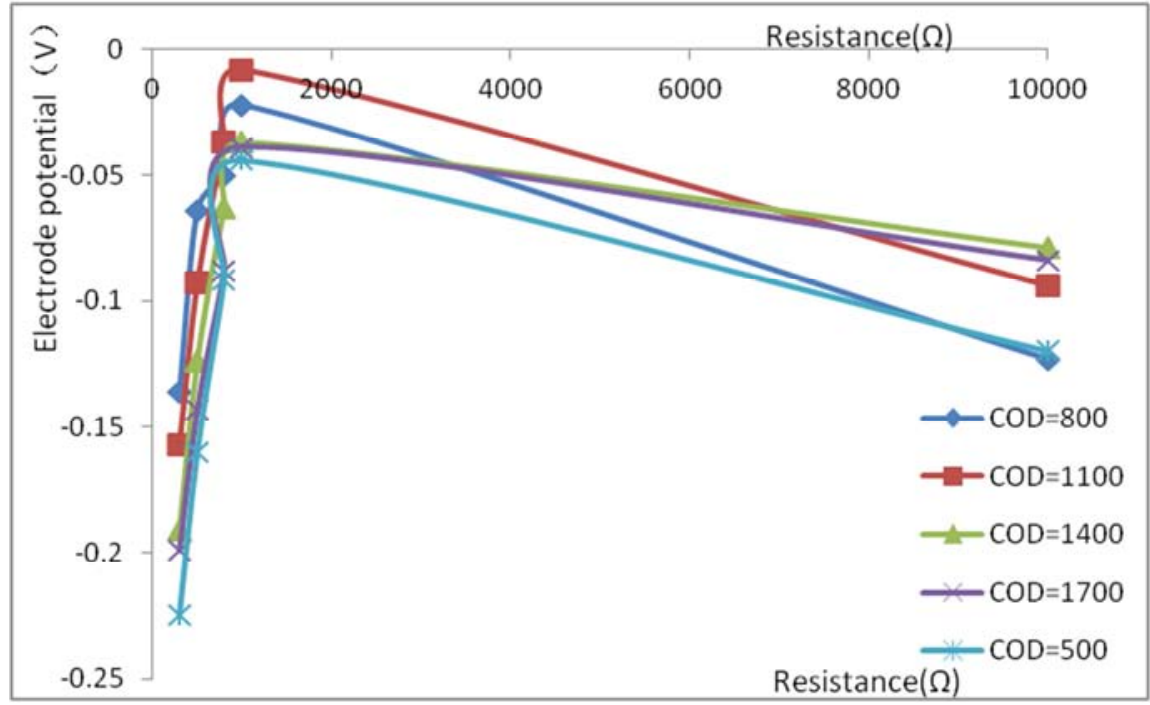

(B)

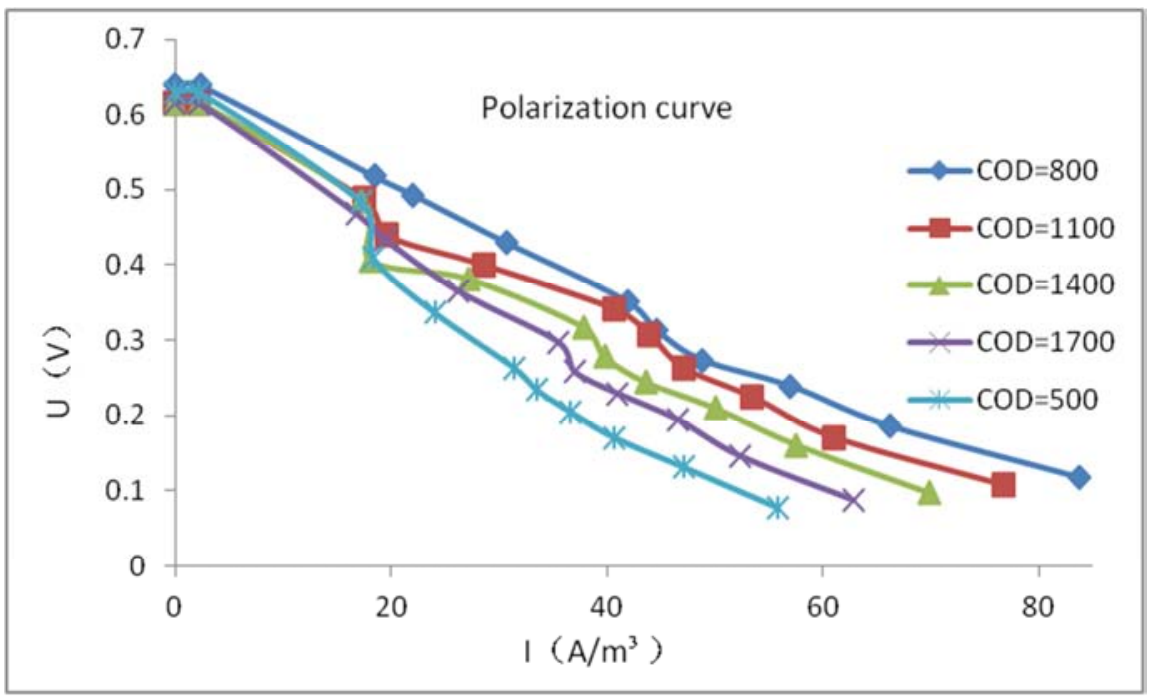

(C) 


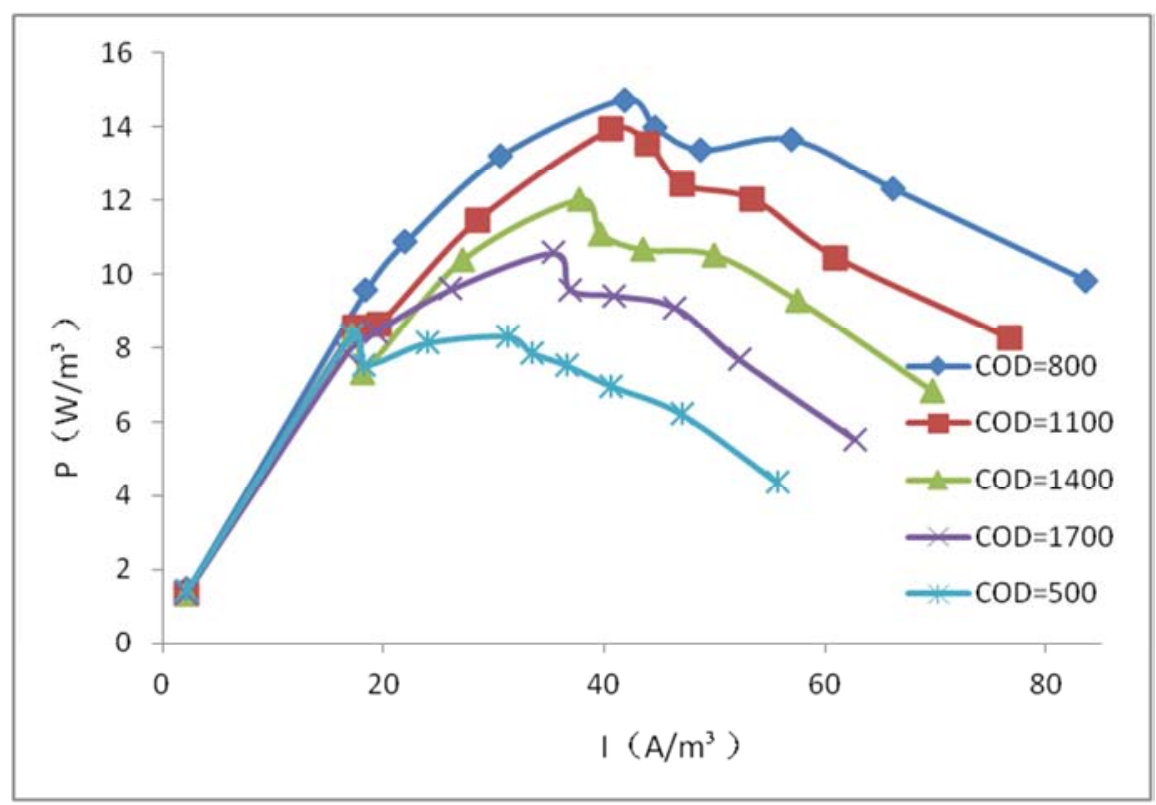

(D)

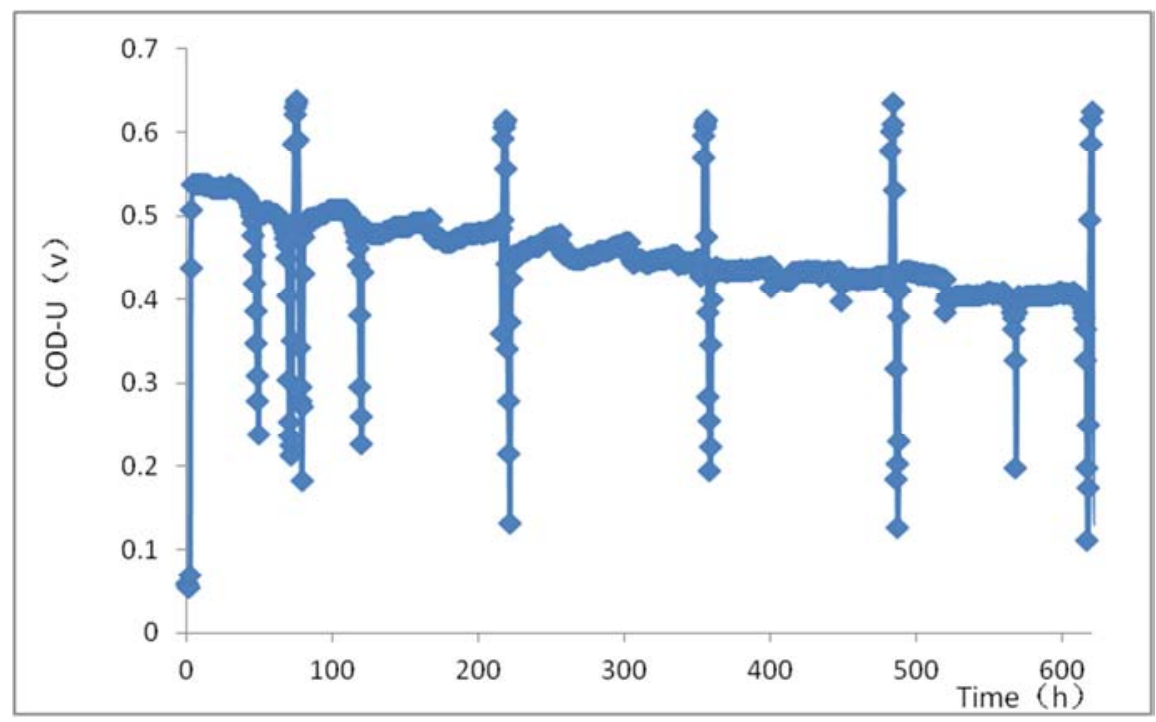

(E)

Figure 7. (A) anode potential diagram; (B) cathode potential diagram; (C) polarization curve; (D) a power density curve; (E) 30min voltage graph with different $C O D$ concentrations in the $M F C$.

Through the measurement of a series of electrochemical parameters, when the measured values were brought into the characterization trend line of 2.4 electrochemical parameters, and compared with the trend line, it could be concluded that when the influent COD concentration changed, it would lead to a great change in power density, current density, the anode and cathode potential, except that the real-time voltage change was relatively stable. After comparison, it could be found that when COD was in the $800-1100 \mathrm{mg} / \mathrm{L}$ interval, the fluctuations of each parameter were small, which meant the reactor operation was stable, as shown in the table below $(\mathrm{COD}=1000 \mathrm{mg} / \mathrm{L}$, real-time voltage was $0.51 \mathrm{~V}$ ).
Table 1. The real-time voltage with different influent COD concentrations in the MFC.

\begin{tabular}{lll}
\hline number & $\mathbf{C O D}(\mathbf{m g} / \mathbf{L})$ & Real-time voltage $(\mathbf{V})$ \\
\hline 1 & $\mathrm{COD}=800$ & 0.53 \\
2 & $\mathrm{COD}=1100$ & 0.48 \\
3 & $\mathrm{COD}=1400$ & 0.43 \\
4 & $\mathrm{COD}=1700$ & 0.42 \\
5 & $\mathrm{COD}=500$ & 0.41 \\
\hline
\end{tabular}

\section{Conclusion}

In this study, by observing the response of electrochemical parameters after changing the concentration gradient of copper ions and measuring the real-time voltage, power density, current density, cathode potential and anode potential 
as the variables in the experiment, it could be concluded that the characterization such as power density, current density, electrode potential were presented in response to $\mathrm{X}^{2}$ except the real-time voltage, which had a linear response. In addition, experiments was also performed to investigate and analyze the effect of influent COD on the electrochemical characterizations, results showed that when $\mathrm{COD}=800$ $\mathrm{mg} / \mathrm{L}$, the response of characterizations was the most stable. In the whole experiments, it has found that microbial fuel cells could be used as the detector of heavy metal in biosensors. This new direction of single chamber MFC development was not only benefit to solve the bottleneck of its development, but also broaden its practical applications using its own characteristics, providing new exploration ideas for the development of microbial fuel cells.

\section{References}

[1] Yan Li, Yining Wu, Sampada Puranik, Yu Lei, Timothy Vadas, Bai kun Li. Metals as electron acceptors in single-chamber microbial fuel cells 2014.269: p. 430-439.

[2] Nancharaiah Y V, Venkata M S, Lens P N. Metals removal and recovery in bioelectrochemical systems: A review [J]. Bioresource Technology, 2015.195: p. 102-114.

[3] Abourached C, Catal T, Liu H. Efficacy of single-chamber microbial fuel cells for removal of cadmium and zinc with simultaneous electricity production.[J]. Water Research, 2014.51(6): p. 228.

[4] Modin O, Wang X, Wu X, et al. Bioelectrochemical recovery of $\mathrm{Cu}, \mathrm{Pb}, \mathrm{Cd}$, and $\mathrm{Zn}$ from dilute solutions [J]. Journal of Hazardous Materials, 2012.291(20): p. 235-236.

[5] Choi $\mathrm{C}, \mathrm{Hu}$ N. The modeling of gold recovery from tetrachloroaurate wastewater using a microbial fuel cell.[J]. Bioresource Technology, 2013, 133C (4): p. 589-598.

[6] Lu Z, Chang D, Ma J, et al. Behavior of metal ions in bioelectrochemical systems: A review [J]. Journal of Power Sources, 2015.275: p. 243-260.

[7] Zhang Y, Yu L, Wu D, et al. Dependency of simultaneous $\mathrm{Cr}(\mathrm{VI}), \mathrm{Cu}(\mathrm{II})$ and $\mathrm{Cd}(\mathrm{II})$ reduction on the cathodes of microbial electrolysis cells self-driven by microbial fuel cells [J]. Journal of Power Sources, 2015.273: p. 1103-1113.

[8] Gangad haran P, Nambi I M, Senthilnathan J. Liquid crystal polaroid glass electrode from e-waste for synchronized removal/recovery of $\mathrm{Cr}(+6)$ from wastewater by microbial fuel cell $[\mathrm{J}]$. Bioresource Technology, 2015.195: p. 96-101.

[9] Tao H C, Min L, Wei L, et al. Removal of copper from aqueous solution by electrodeposition in cathode chamber of microbial fuel cell [J]. Journal of Hazardous Materials, 2011.189(1-2): p. 186-192.

[10] Wang Z, Lim B, Choi C. Removal of $\mathrm{Hg} 2+$ as an electron acceptor coupled with power generation using a microbial fuel cell [J]. Bioresource Technology, 2011.102(10): p. 63046307.

[11] Tandukar M, Huber S J, Onodera T, et al. Biological chromium(VI) reduction in the cathode of a microbial fuel cell. [J]. Environmental Science \& Technology, 2009.43(21): p. $8159-8165$.

[12] Li H, Feng Y, Zou X, et al. Study on microbial reduction of vanadium matallurgical waste water $[\mathrm{J}]$. Hydrometallurgy, 2009.99(1-2): p. 13-17.

[13] You J, Walter X A, Greenman J, et al. Stability and reliability of anodic biofilms under different feedstock conditions: Towards microbial fuel cell sensors [J]. Sensing and BioSensing Research, 2015.6(9):43-50.

[14] Velling S, Tenno T. Different calibration methods of a microbial BOD sensor for analysis of municipal wastewaters [J]. Sensors \& Actuators B Chemical, 2009.141(1): p. 233238.

[15] Stein N E, Hamelers H M V, Straten G V, et al. On-line detection of toxic components using a microbial fuel cellbased biosensor [J]. Journal of Process Control, 2012.22(9): p. 1755-1761.

[16] Shen Y J, Lefebvre O, Tan Z, et al. Microbial fuel-cell-based toxicity sensor for fast monitoring of acidic toxicity [J]. Water Science \& Technology, 2012.65(7): p. 1223-1228.

[17] Stein, N, E, Hamelers HVM, Buisman CNJ. Stabiliz -ing the baseline current of a microbial fuel cell-based biosensor through over potential control under non-toxic conditions [J]. Bioelectrochemistry, 2010.78(1): p. 87-91. 